\title{
Living environment and health of under-five children in urban slums of a coastal region in South India
}

\author{
Roja VR ${ }^{1}$, Prakash Narayanan ${ }^{2}$ Varalakshmi Chandra Sekaran ${ }^{3}$ and Ajith Kumar MG $^{4}$ \\ Ghana Med J 2020; 54(4): 238-244 doi: http://dx.doi.org/10.4314/gmj.v54i4.6
}

\author{
${ }^{1}$ ICMR NTF HI project, Dept. of ENT \& HNS, AIIMS Raipur, India \\ ${ }^{2}$ Prasanna School of Public Health, MAHE, Manipal, India \\ ${ }^{3}$ epartment of Community Medicine, Melaka Manipal Medical College, MAHE, Manipal, India \\ ${ }^{4}$ Baby Memorial Hospital and Malabar Hospital, Calicut, Kerala, India
}

\author{
Corresponding author: Varalakshmi Chandra Sekaran \\ Conflict of interest: None declared
}

E-mail:varalakshmi.cs@manipal.edu

\begin{abstract}
SUMMARY
Objective: The primary objective of the study was to determine the association between the living environment and morbidity, nutritional status, immunization status, and personal hygiene of under-five children living in urban slums in southern India.

Methods: This study included 224 mothers of under-five children living in urban slums of Udupi Taluk, Karnataka. A total of 17 urban slums were selected randomly using random cluster sampling.

Results: Undernutrition was high among children of illiterate mothers (63.8\%), and the children of working mothers were affected by more morbidity $(96.6 \%)$ as compared with housewives. Morbidity was also found to be high among children belonging to families with low incomes (66.1\%) and low socio-economic backgrounds (93.1\%). Safe drinking water, water supply, sanitation, hygiene, age of the child, mother's and father's education, mother's occupation and age, number of children in the family, use of mosquito nets, type of household, and family income were significantly associated with child morbidity, nutritional status, immunization status, and personal hygiene of under-five children living in urban slums.

Conclusion: Overall, in our study, family characteristics including parental education, occupation and income were significantly associated with outcomes among under-five children. The availability of safe drinking water and sanitation, and the use of mosquito nets to prevent vector-borne diseases are basic needs that need to be urgently met to improve child health.
\end{abstract}

Key Words: Child morbidity; under-five children; hygiene; slums; India Funding: Self-funded

\section{INTRODUCTION}

According to the constitution of the World Health Organization 1948 "Healthy development of the child is of basic importance; the ability to live harmoniously in a changing total environment is essential to such development". ${ }^{1}$ As cities develop, urbanization is emerging as a public health challenge. There has been consistent growth in the urban population from $18 \%$ to $33 \%$ between 1955 and 2015. Urbanization leads to the establishment of slums, which continue to lack basic sanitary facilities and safe drinking water, healthcare, housing needs, and educational deficits which pose as growing concerns. The lack of these basic services has both a direct and indirect effect on the health of the urban slum dwellers2. The Sustainable Development Goals ${ }^{2}$ through ${ }^{6}$ West Bengal, Rajasthan and Gujarat which enumerated more than $81 \%$ slum population and 1955 slum towns ${ }^{4}$.There is a steady growth in the slum population in the developing world with an estimated 881million in 2014 in comparison with 792 million in the year 2000. Per the Census of India, 2011 $1^{5,6}$ several Indian states including Karnataka contribute to about 1955 slum towns. It is also estimated that every fourth Indian child lives in an urban setting. The number of children between the ages of 0-6 years in urban areas has shown an increase since 2001 while a steady decline has been simultaneously observed in rural areas ${ }^{7}$. About 7.8 million children, accounting for $6.07 \%$, live in urban slums. ${ }^{8}$ Children living in slums are 1.3 times likely to suffer from diarrhoea than those in non-slum areas. ${ }^{9}$ About 300 million people living in urban India face exclusion from essential health services and other services like safe drinking water, sanitation, education, and access to essential 


\section{Original Article}

services and most often their births or deaths are not registered. Children are prone to diseases and disasters. ${ }^{2,-14}$. According to the National Family and Health Survey (NFHS)-4 only $63.9 \%$ of the urban poor children get fully immunized, $49.8 \%$ of urban poor under-five children were underweight. ${ }^{2,10}$ The sustainable development goals (SDG) envisage the end of malnutrition among the most vulnerable by the year 2030 and the World Health Organization hopes to reduce childhood wasting below $5 \%{ }^{12}$

On assessing the Global Hunger Index reflecting severity in hunger levels, undernourishment, child wasting, stunting, and mortality, India's performance begs further efforts ${ }^{15}$. Slum-dwellers are largely migrants and are mobile who live in unhygienic and insanitary conditions. Coupled with lower educational status, reduced awareness on health and nutrition and comparatively reduced access to healthcare, this poses a risk of increased morbidity among the most vulnerable groups, including women and children. There is a paucity of literature related to the health of urban slum dwellers, especially of children. In this regard, our study aimed to estimate the morbidity, nutritional and immunization status and personal hygiene of children living in urban slums and their association if any with their living conditions, socio-economic and demographic characteristics of the slum population in Udupi taluk.

\section{METHODS}

Study design: This community-based cross-sectional study was designed to study the association of the living environment on child morbidity, nutrition, immunization status, and personal hygiene of under-five children living in urban slums of Udupi taluk, Karnataka.

\section{Sampling}

Random sampling was used to select slums. Seven slums were randomly selected from a list of 27 slums collated from the Municipality and Mission Indradhanush16. This was a mission launched by the Ministry of Health and Family Welfare (MOHFW) Government of India. Cluster sampling technique was used for the selection of households and children in selected slums. A complete enumeration of eligible mothers of under-five children from all selected clusters. If there were more than one eligible under-five children in the selected household, data on the youngest child was collected. The sample size was calculated using the formula for cross-sectional studies ${ }^{17}$, using $\mathrm{Z} \alpha=1.96, \mathrm{p}=43 \%$ was the prevalence from previous study ${ }^{18}$, q was $1-\mathrm{p}$, d was $15 \%$ relative precision as the researcher wanted to estimate the prevalence to within 5 percentage points of the true value at $95 \%$ confidence and therefore, the sample size was 224 .
Study participants: A total of 17 urban slums were selected randomly and complete enumerations of all mothers of under-five children from all selected slums were carried out. Mothers of children who were absent during more than two consecutive visits were excluded from the study.

\section{Ethical considerations}

Ethical clearance was obtained from the Institutional Ethical Committee at a tertiary care hospital in Manipal (IEC 438/2015). Written consent was obtained from all the participants in the study.

\section{Data collection}

A structured questionnaire was prepared following review of the literature and this was used for the collection of data. The tool was self-administrated and the interviewer was available to clarify any questions that the interviewee may have had. Nutritional status of under-five children was assessed by including anthropometric measurements like height, weight, and Z-scores were calculated according to National Centre for Health Statistics (NCHS) reference data for age and sex of the child endorsed by the World Health Organiztion. ${ }^{18}$

Children were classified as underweight and normal weight. Undernutrition was the weight for age less than 2SD of the NFHS reference ${ }^{18}$. The weight of the underfive children was measured using a digital weighing machine. To ascertain the information about immunization coverage, the respondent was asked to provide their immunization card if they had any. In the case of non-availability of the card, information regarding the administration of vaccines was recorded on the basis of the respondent's memory. For BCG, the immunization status was assessed by the presence of the scar.

For this study, morbidity conditions were assessed using the presence of one or more conditions such as skin infections, diarrhoea, fever, cough, pneumonia, eye or ear infections, angular stomatitis, and caries. Personal hygiene was measured using general appearance, bathing practices, hair, nose, mouth, tongue if white coated, teeth and nail hygiene. The living environment of a child was defined as all external factors which may affect the normal growth of child including housing, safe drinking water, sanitation and socio-demographic profile of the parents. ${ }^{11}$

\section{Data analysis}

The data was entered and analyzed in SPSS version ${ }^{15}$. The data were summarized using descriptive statistics. Statistical differences between categorical variables were assessed using the Chi-square or Fisher exact test (if cell value was less than 5) and means were compared using 
the Student's T-test. The p-value $<0.05$ was considered statistically significant.

\section{RESULTS}

A total of 224 mothers of under-five children participated in this study, the mean age of children was $28 \pm 1.6$ months and the majority were boys $(58.5 \%)$. The mean age of father was $32.4 \pm 2.5$ years and mothers' mean age was $22.9 \pm 4.3$ years.
Most of the parents were daily labourers. More than twothirds $(67.4 \%)$ of the families had only one under-five child, and $85.7 \%$ were Hindus. About $38 \%$ had a monthly family income below Rs.5000 ( $\$ 68)$, and $88 \%$ of children were living in kutcha (mud bricks) households. Most (84.4\%) of the slums had drinking water supply and more than three-fourths (76\%) of the households did not purify or boil their drinking water. None of the households had a toilet facility within the premises, and $64.7 \%$ practised open defecation.

Figure 1 Proportion of under-five children by morbidity based on general and physical examination (Multiple conditions reported) $n=174$

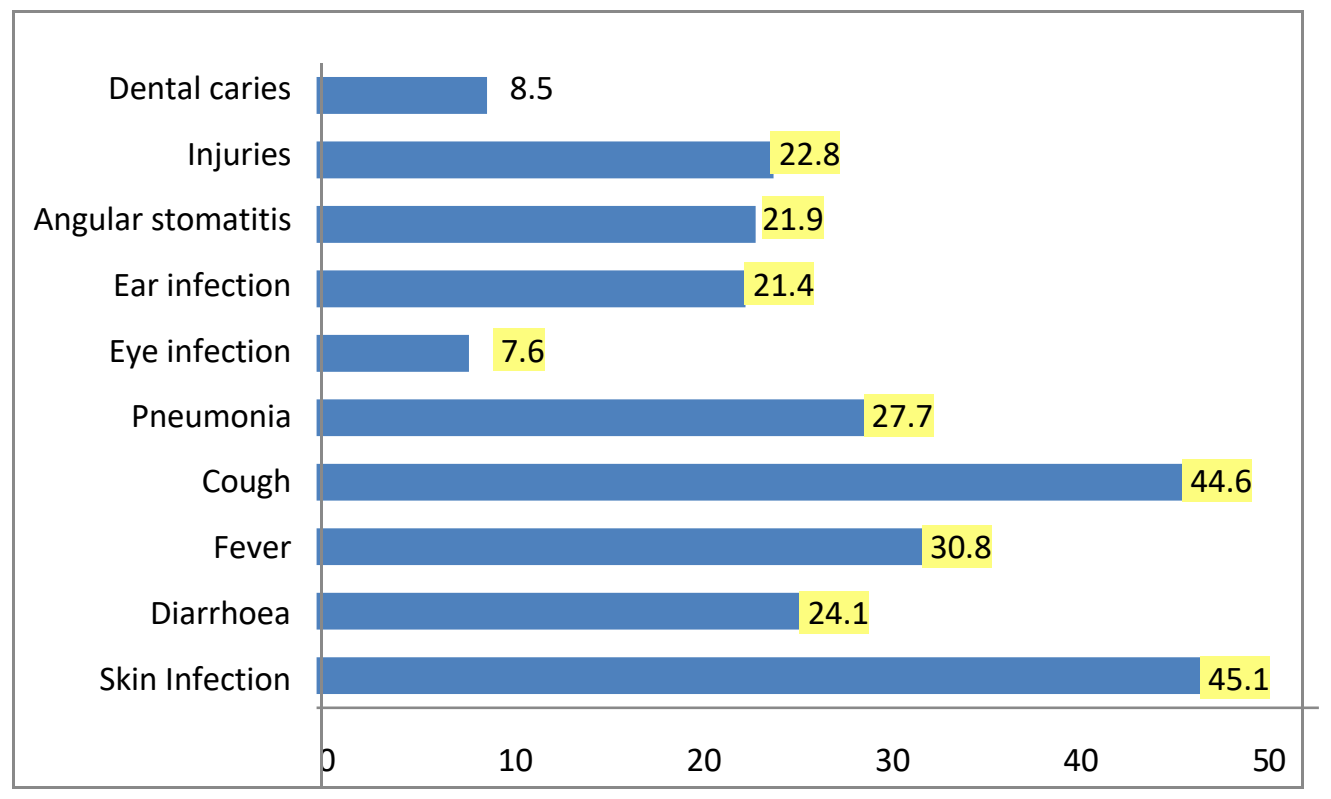

On assessing under-five morbidity by age group (in months), it was observed that the highest percentage of morbidities (31\%) were among children aged 23-35 months, followed by $29 \%$ among children aged $12-22$ months with the least reported among those less than 12 months of age (11\%).

Most common morbidities identified were skin infections and cough which constituted $45.1 \%$ and $44.6 \%$ respectively followed by fever (30.8\%), pneumonia (27.7\%), diarrhoea (24.1\%), injuries (22.8\%), angular stomatitis (21.9\%), ear infection (21.4\%) and eye infection (7.6\%). Majority of the children (59.8\%) aged between 12 to 35 months were suffering from various morbidities. Morbidity was significantly high among young children, whose mothers were younger $(\mathrm{p}=0.042)$ and children of illiterate women $(\mathrm{p}=0.039)$. Child morbidity was found to be significantly associated working status of mother $(p=0.001)$ and those having a family income of more than Rs 5000 per month and those living in kutcha households $(\mathrm{p}=0.001)$.

Morbidity conditions were found to be significantly higher among those who did not use safe or potable drinking water $(p=0.009)$. Significant variations between morbidity and inadequate water supply were noted $(\mathrm{p}=0.001)$. Morbidity was high among children who were not using mosquito nets $(\mathrm{p}=0.021)$. Morbidity was significantly associated with personal hygiene $(\mathrm{p}=0.001)$ as $83 \%$ of the under-five morbid children were not having good personal hygiene. The study showed that personal hygiene was found to be significantly associated with skin infections $(\mathrm{p}=0.041)$.

The majority (63\%) of children with skin infections had poor personal hygiene. Personal hygiene was significantly associated with cough $(\mathrm{p}=0.003)$ with almost half (49.7\%) of the children who had poor personal hygiene, 
suffering from a cough. Among the children who did not have adequate personal hygiene, $26.6 \%$ had diarrhoea, $30.5 \%$ had pneumonia, $35 \%$ had fever, $24.3 \%$ had angular stomatitis and $22 \%$ had ear infections respectively. Children with good personal hygiene showed a smaller number of eye infections (8.1\%), dental caries (23.4\%) and injuries.

This study shows that undernutrition had a significant association with mothers' education $(\mathrm{p}=0.039)$. The proportion of undernourished children was higher among those whose mothers were illiterate $(76.7 \%)$ as compared to those who were literate. Undernutrition was more among children belonging to families with a family income of less than Rs. 5000 (\$68) (78.1\%). Undernutrition was significantly associated with family income $(\mathrm{p}=0.02)$. Children who were living in kutcha households also had higher rates of undernutrition (97.3\%). A significant association between undernutrition and type of household was noted at $\mathrm{p}=0.001$. (Table 1 )

Table 1 Association between socio-demographic factors and childhood morbidity

\begin{tabular}{|c|c|c|c|c|c|}
\hline \multirow[b]{2}{*}{ Variables } & \multirow[b]{2}{*}{$\begin{array}{l}\text { Cate- } \\
\text { gory }\end{array}$} & \multicolumn{2}{|c|}{ Morbidity } & \multirow[b]{2}{*}{$\chi^{2}$} & \multirow[b]{2}{*}{$\begin{array}{l}\text { p- } \\
\text { value }\end{array}$} \\
\hline & & Yes & No & & \\
\hline $\begin{array}{l}\text { Child age in } \\
\text { month }\end{array}$ & mean $\pm \mathrm{SD}$ & $26.7 \pm 1.5$ & $30 \pm 1.6$ & $1.56^{*}$ & 0.214 \\
\hline Mother's age & mean $\pm \mathrm{SD}$ & $22.6 \pm 4.04$ & $\begin{array}{l}24.08 \pm 5.2 \\
3\end{array}$ & $\begin{array}{l}4.195 \\
*\end{array}$ & 0.042 \\
\hline \multirow{2}{*}{$\begin{array}{l}\text { Mother's ed- } \\
\text { ucation }\end{array}$} & Literate & $63(36.20)$ & $10(20.0)$ & \multirow[b]{2}{*}{4.644} & \multirow[t]{2}{*}{0.039} \\
\hline & Illiterate & $111(63.8)$ & $40(80.0)$ & & \\
\hline \multirow{2}{*}{$\begin{array}{l}\text { Mother's oc- } \\
\text { cupation }\end{array}$} & Working & $168(96.6)$ & $33(68.0)$ & \multirow[t]{2}{*}{39.34} & \multirow[t]{2}{*}{0.001} \\
\hline & Housewife & $6(3.4)$ & $16(32.0)$ & & \\
\hline \multirow{2}{*}{$\begin{array}{l}\text { Monthly in- } \\
\text { come (Rs.) }\end{array}$} & $>5000$ & $115(66.1)$ & $24(48.0)$ & \multirow[t]{2}{*}{5.399} & \multirow[t]{2}{*}{0.020} \\
\hline & $<5000$ & $59(33.9)$ & $26(52.0)$ & & \\
\hline \multirow[t]{2}{*}{$\begin{array}{l}\text { Type of } \\
\text { household }\end{array}$} & $\begin{array}{l}\text { Semi } \\
\text { pucca }\end{array}$ & $10(5.7)$ & $16(32.0)$ & \multirow[t]{2}{*}{26.09} & \multirow[t]{2}{*}{0.001} \\
\hline & Kutcha & $164(94.3)$ & $34(68.0)$ & & \\
\hline \multirow{2}{*}{$\begin{array}{l}\text { Purified } \\
\text { drinking wa- } \\
\text { ter }\end{array}$} & Yes & $35(20.1)$ & $19(38.0)$ & \multirow[t]{2}{*}{6.791} & \multirow[t]{2}{*}{0.009} \\
\hline & No & $139(79.9)$ & $31(62.0)$ & & \\
\hline \multirow{2}{*}{$\begin{array}{l}\text { Adequate } \\
\text { water supply }\end{array}$} & Yes & 153(87.9) & $29(58.0)$ & \multirow{2}{*}{$\begin{array}{l}22.84 \\
0\end{array}$} & \multirow[t]{2}{*}{0.001} \\
\hline & No & $21(12.1)$ & $21(42.0))$ & & \\
\hline \multirow{2}{*}{$\begin{array}{l}\text { Using mos- } \\
\text { quito nets }\end{array}$} & Yes & $50(28.7)$ & $10(20.0)$ & \multirow[t]{2}{*}{1.511} & \multirow[t]{2}{*}{0.021} \\
\hline & No & $124(71.3)$ & $40(80.0)$ & & \\
\hline \multirow{2}{*}{$\begin{array}{l}\text { Good per- } \\
\text { sonal hygiene }\end{array}$} & Yes & $28(16.1)$ & $19(38.0)$ & \multirow[t]{2}{*}{11.24} & \multirow[t]{2}{*}{0.001} \\
\hline & No & $146(83.9)$ & $31(62.0)$ & & \\
\hline
\end{tabular}

The study observed a significant association between undernutrition and immunization status $(\mathrm{p}=0.042)$. Majority of the undernourished children were not fully immunized $(72.6 \%)$. Immunization status was found to have a significant association with the number of children in the family $(p=0.041)$. The majority of those children who were fully immunized lived in households with a smaller number of children. Immunization status was significantly associated with the child's age $(p=0.001)$. Lower aged children were fully immunized as compared to older aged children (mean age of fully immunized children was $29 \pm 7$ months). About (73.5\%) of fully immunized children's fathers were educated, and immunization was significantly associated with father's education $(\mathrm{p}=0.041)$. (Table 2)

Table 2 Association between morbidity conditions and personal hygiene

\begin{tabular}{|c|c|c|c|c|c|}
\hline \multirow[t]{2}{*}{ Variables } & \multirow{2}{*}{$\begin{array}{l}\text { Cate- } \\
\text { gory }\end{array}$} & \multicolumn{2}{|c|}{ Good Personal hygiene } & \multirow[t]{2}{*}{$\chi^{2}$} & \multirow{2}{*}{$\begin{array}{l}\text { p- } \\
\text { value }\end{array}$} \\
\hline & & Yes & No & & \\
\hline \multirow[t]{2}{*}{ Skin infection } & Yes & $15(31.9)$ & $86(48.6)$ & \multirow[t]{2}{*}{4.170} & \multirow[t]{2}{*}{0.041} \\
\hline & No & $32(68.1)$ & $91(51.4)$ & & \\
\hline \multirow[t]{2}{*}{ Fever } & Yes & $7(14.9)$ & $62(35)$ & 7.064 & 0.008 \\
\hline & No & $40(85.1)$ & $115(65)$ & & \\
\hline \multirow[t]{2}{*}{ Cough } & Yes & $12(25.5)$ & $88(49.7)$ & 8.790 & 0.003 \\
\hline & No & $35(74.5)$ & $89(50.3)$ & & \\
\hline
\end{tabular}

Table 3 Association between socio-demographic factors and childhood undernutrition

\begin{tabular}{|c|c|c|c|c|c|}
\hline \multirow[t]{2}{*}{ Variable } & \multirow[t]{2}{*}{ Category } & \multicolumn{2}{|c|}{ Undernutrition } & \multirow[t]{2}{*}{$\chi^{2}$} & \multirow[t]{2}{*}{ p-value } \\
\hline & & Yes & No & & \\
\hline \multirow[t]{2}{*}{ Mother's education } & Literate & $17(23.3)$ & $55(36.4)$ & \multirow[t]{2}{*}{3.893} & \multirow[t]{2}{*}{0.048} \\
\hline & Illiterate & $56(76.7)$ & $96(63.6)$ & & \\
\hline \multirow[t]{2}{*}{ Monthly income (Rs.) } & $>5000$ & $57(78.1)$ & $85(56.3)$ & \multirow{2}{*}{$\begin{array}{l}10.06 \\
9\end{array}$} & \multirow[t]{2}{*}{0.002} \\
\hline & $<5000$ & $16(21.9)$ & $66(43.70$ & & \\
\hline \multirow[t]{2}{*}{ Type of household } & $\begin{array}{l}\text { Semi- } \\
\text { pucca }\end{array}$ & $2(2.7)$ & $24(15.9)$ & \multirow[t]{2}{*}{8.299} & \multirow[t]{2}{*}{0.004} \\
\hline & kutcha & $71(97.3)$ & $127(84.1)$ & & \\
\hline \multirow[t]{2}{*}{ Adequate water supply } & Yes & $54(74.0)$ & $128(84.8)$ & \multirow[t]{2}{*}{3.7} & \multirow[t]{2}{*}{0.051} \\
\hline & No & $19(26.0)$ & $23(15.2)$ & & \\
\hline $\begin{array}{l}\text { Number of children in } \\
\text { thefamily }\end{array}$ & Mean \pm SD & $2.5 \pm 4.2$ & $2.8 \pm 1.1$ & $4.26^{*}$ & 0.041 \\
\hline $\begin{array}{l}\text { Number of under five } \\
\text { childrenin the family }\end{array}$ & Mean \pm SD & $\begin{array}{l}1.43 \pm 0.0 \\
4\end{array}$ & $1.3 \pm 0,4$ & $\begin{array}{l}3.390 \\
*\end{array}$ & 0.060 \\
\hline Child's age & Mean \pm SD & $13.29 \pm 7$ & $35.9 \pm 1$ & $\begin{array}{l}188.4 \\
69 *\end{array}$ & 0.001 \\
\hline \multirow[t]{2}{*}{ Father's education } & Literate & $61(73.5)$ & $84(59.6)$ & \multirow[t]{2}{*}{4.596} & \multirow[t]{2}{*}{0.041} \\
\hline & Illiterate & $22(26.5)$ & $57(40.4)$ & & \\
\hline
\end{tabular}

Table 4 Association between socio-demographic factors and immunization status

\begin{tabular}{|c|c|c|c|c|c|}
\hline \multirow[t]{2}{*}{ Variables } & \multirow[t]{2}{*}{ Category } & \multicolumn{2}{|c|}{ Immunization } & \multirow[t]{2}{*}{$\chi^{2}$} & \multirow[t]{2}{*}{ p-value } \\
\hline & & Yes & No & & \\
\hline $\begin{array}{l}\text { Number } \\
\text { children } \\
\text { family }\end{array}$ & Mean \pm SD & $2.5 \pm 4.2$ & $2.8 \pm 1.1$ & 4.26 & 0.041 \\
\hline Child age & Mean \pm SD & $13.29 \pm 7$ & $35.9 \pm 1$ & $188.469^{*}$ & 0.001 \\
\hline \multirow{2}{*}{$\begin{array}{l}\text { Father's edu- } \\
\text { cation }\end{array}$} & Literate & $61(73.5)$ & $84(59.6)$ & \multirow[t]{2}{*}{4.596} & \multirow[t]{2}{*}{0.041} \\
\hline & Illiterate & $22(26.5)$ & $57(40.4)$ & & \\
\hline Total & & $83(100)$ & 141(100) & 224 & \\
\hline
\end{tabular}

\section{DISCUSSION}

Undernutrition was high among children of illiterate mothers $(63.8 \%)$ and the children of working mothers were affected by more morbidities (96.6\%) as compared to children of mothers who were homemakers. 
Morbidity was also found to be high among children belonging to families with low income $(66.1 \%)$ and low socio-economic backgrounds (93.1\%). Similar findings have been reported by Tada $\mathrm{Y}$ et $\mathrm{al}^{19}$, Abuya BA et $\mathrm{al}^{20}$, and Safikul Islam et $\mathrm{al}^{21}$ where the prevalence of underweight children was consistent with this study.

The most common morbidities among the children were skin infection $(45.1 \%)$, fever $(30.8 \%)$, cough $(44.6 \%)$, pneumonia $(27.7 \%)$ and diarrhoea $(24.1 \%)$. These findings are similar to the findings of studies in other settings by Adhikari $\mathrm{D}$ et $\mathrm{al}^{22}$, Srivastava $\mathrm{DK}$ et $\mathrm{al}^{23}$, Taffa $\mathrm{N}$ et $\mathrm{al}^{23}$. These morbidities were associated with lack of personal hygiene, mother's age, her education and occupation, family income and type of household which are findings similar to other studies ${ }^{(24-26)}$. In the Indian context, a study conducted by Ukey UU et $\mathrm{a}^{25}$ in urban slums of Visakhapatnam showed a higher prevalence of morbidity conditions (82\%) among under-five children.

A study conducted in Nepal reported a considerably higher prevalence $(60 \%)$ of underweight children in urban slums ${ }^{21}$. Also, a study in the urban slums of Etawah ${ }^{22}$ showed a prevalence of undernutrition at $37.1 \%$ among children of mothers in the age group of 20-35 years that is consistent with the present study where the mean age of mothers of under-nourished children was found to be $22.9 \pm 4.04$.

In this study, $38.8 \%$ of the under-five children were fully immunized with the majority (65.1\%) being male. BCG vaccination was given to $90.2 \%$ of the children but vaccination coverage for measles was low (28.1\%). These findings are similar to a study conducted by Sharma $\mathrm{R}$ et $\mathrm{al}^{27}$ where total immunization coverage was $25 \%$, BCG vaccination coverage was $75 \%$, and measles vaccination coverage was $29.9 \%$. This study also shows that the number of children of younger parents who were fully immunized was more than children of relatively older parents (mean age of fully immunized children's mother was $22.5 \pm 4.4$ and fathers was $30 \pm 6.5$ ).

Majority of the fully immunized children's parents had a lower number of children. Lower aged children were fully immunized as compared to higher aged children (mean age of fully immunized children was $29 \pm 7$ months). Among fully immunized children, $73.5 \%$ \& $34.9 \%$ of their fathers and mothers were educated respectively. This was found to be consistent with a study conducted among 746 rural to urban migrant mothers with children aged up to 2 years by Kusuma YS et al. ${ }^{29}$ It was also found that mother's age; educational status; the frequency of health care use; head of the family's education, job and income were significantly associated with full immunization coverage.
A study conducted in an unregistered slum of Mumbai by Banerjee $\mathrm{J}$ et $\mathrm{al}^{30}$ showed that $43 \%$ of mothers did not have an immunization card recording the immunization status of their child which is consistent with the present study.

This study was not without its limitations. Morbidity status was based on self-reported signs and symptoms which were not confirmed by clinical examinations or diagnostic tests. Immunization status might be under-reported as the immunization card was used to verify immunization status in this study. Many of the parents could not produce the card at the time of data collection. Only weight for age was used to assess the health status of children in this study. Several respondents refused to give written consent although they were ready to participate and gave verbal consent.

Healthcare needs to be made accessible for mobile and migrant slum populations without the hassle of documentation. Provision of basic needs, adequate and safe drinking water supply, sanitary facilities, mosquito nets and shelter to improve life in the slums need to be prioritized as they represent a specific vulnerable group.

\section{CONCLUSION}

Overall, in our study, family characteristics including parental education, occupation and income were found to be statistically significantly associated with childhood outcomes. Undernutrition was high among children of illiterate mothers and less than half of the under-five children were fully immunized. The availability of safe drinking water and sanitation and the use of mosquito nets to prevent vector-borne diseases were basic needs that need to be urgently met to improve child health.

\section{REFERENCES}

1. World Health Organization. Constitution of The World Health Organization [Internet]. Basic Document Forty-fifth edition. October 2006. [Cited 10 Dec 2018] Availablefrom:http://www.who.int/governance/eb/who_constitution_en.pdf.(2)

2. Usmani $\bar{G}$, Ahmad N. Health status in India: A study of urban slum and non-slum population. $J$ Nurs Res Pract 2018;2(1): 09-14.

3. Ayog N. SDG India Base Line Index. Government of India, New Delhi. 2018. [Cited 10 Dec 2018] Available from: niti.gov.in > content > sdg-India-index-baseline-report-2018

4. Kumar P. Rain Water Harvesting and Artificial recharge in Haryana. J Environ Soc Sci. 2016;3(1): 124. 


\section{Original Article}

5. Chandramouli C. Census of India 2011, Provisional population totals, paper 1 of 2011, India series 1. October. 2011.

6. GOI. Census of India : Housing Stock, Amenities \& Assets in Slums - Census 2011 [Internet]. Office of the Registrar General \& Census Commissioner, India. 2011 [cited 2020 May 7] Available from: http://censusindia.gov.in/2011census/hlo/Slum_table/Slum table.html

7. Habitat UN. State of the world's cities 2012/2013: Prosperity of cities. 2013. 1-184. doi:10.4324/9780203756171

8. Status of children in urban India, Baseline study 2016. National Institute of Urban Affairs, Bernard van Leer Foundation. [cited 2020 September 10]. Available from: https://cfsc.niua.org/sites/default/files/Status of children in urban IndiaBaseline_study_2016.pdf

9. Kavitha $\bar{N}$. Are slum children at high risk of undernutrition, anaemia and childhood morbidity? Evidence from India. Indian Journal of Community Health. 2014 Jun 30;26(2):124-31.

10. National family health survey (NFHS-4) 20015-16, India. Mumbai: International Institute for Population Sciences (IIPS) and ICF. [Cited 08 April 2020] Available from: http://rchiips.org/NFHS/factsheet NFHS- 4.shtml.

11. Roja VR, Galhotra A, Rajan AV, Malarout N, Pateria S, Kamath R. Health status of under-five children living in urban slums. Indian Journal of Public Health Research \& Development. 2018;9(10):195-201. doi: 10.5958/09765506.2018 .01340 .2

12. Roy MP. Under-five malnutrition in Indian slums. Journal of Dr. NTR University of Health Sciences. 2017.1;6(4):270. 10.4103/jdrntruhs.jdrntruhs_60_17

13. Liu L, Oza S, Hogan D, Perin J, Rudan I, Lawn JE, Cousens S, Mathers C, Black RE. Global, regional, and national causes of child mortality in 2000-13, with projections to inform post-2015 priorities: an updated systematic analysis. The Lancet. 2015 Jan 31;385(9966):430-40.

DOI: https://doi.org/10.1016/S0140-6736(16)31593-8

14. Singh J, Mondal N. Assessment of nutritional status: A case of tribal children in Assam, Northeast India. $J$ Nepal Paediatr Soc. 2013;33 (1):1-7. DOI: https://doi.org/10.3126/jnps.v33i1.7404

15. Grebmer KV, Bernstein J, Patterson F, Sonntag A, Klaus LM, Fahlbusch J et al. 2018 Global Hunger Index: Forced Migration and Hunger. October 2018. Concern Worldwide, Welt hunger hilfe; [Cited 10 Dec 2018] Available from https://www.globalhungerindex.org/pdf/en/2018.pdf
16. Bashar MA. Success story of mission Indradhanush: a road to achieve universal immunization. Natl $J$ Community Med. 2016;7(5):455-6.

17. Pourhoseingholi MA, Vahedi M, Rahimzadeh M. Sample size calculation in medical studies. Gastroenterology and Hepatology from bed to bench. 2013;6(1):14.

18. Arnold F, Parasuraman S, Arokiasamy P, Kothari M. Nutrition in India. National Family Health Survey (NFHS- 3), India. 2005;6:59.

19. Tada Y, Keiwkarnka B, Pancharuniti N, Chamroonsawasdi K. Nutritional status of the preschool children of the Klong Toey Slum, Bangkok. Southeast Asian J Trop. Med Public Health. 2002; 33 (3):628-37. PMID:12693602

20. Abuya BA, Ciera J, Kimani-Murage E. Effect of mother's education on child's nutritional status in the slums of Nairobi. BMC Pediatr [Internet]. 2012;12(1):80. doi: https://doi.org/10.1186/14712431-12-80

21. Islam $\mathrm{S}$, Mahanta TG, Sarma R, and Hiranya S. Nutritional Status of under 5 Children belonging to Tribal Population Living in Riverine (Char) Areas of Dibrugarh District, Assam; Indian J Community Med. 2014 Jul-Sep; 39(3): 169-174. doi: 10.4103/0970-0218.137155

22. Adhikari, D. A Study On Health Status Of Children Under Five Years Of Age In A Rural Village Of Eastern Part Of Nepal. Journal of Nobel Medical College (2013):2(1) 49-54. https://doi.org/10.3126/jonmc.v2i1.7676

23. Srivastava DK, Tripathi D, Gour N, Jain PK, Singh $\mathrm{CM}$, Srivastava AK, et al. Morbidity profile of under-five children in urban slums of Etawah district. Indian J Community Heal. 2012;24 (2):153-7. DOI: 10.18231/2394-6776.2018.0037.

24. Taffa N, Chepngeno G, Amuyunzu-Nyamongo M. Child morbidity and healthcare utilization in the slums of Nairobi, Kenya.J Trop Pediatr. 2005; 51 (5):279-84. doi: 10.1093/tropej/fmi012

25. Keraka MN, Wamicha WN. Child morbidity and mortality in slum environments along Nairobi River. East Afr Soc Sci Res Rev. 2003;19(1):41-57 doi: 10.1353/eas.2002.0013

26. Ukey UU, Chitre DS. Morbidity profile of preschool children in an urban slum area. Indian Medical Gazette. 2012 Aug:300-4.

27. Rah JH, Cronin AA, Badgaiyan B, Aguayo VM, Coates S, Ahmed S. Household sanitation and personal hygiene practices are associated with child stunting in rural India: a cross-sectional analysis of surveys. BMJ Open [Internet]. 2015;5(2): e005180. doi: 10.1136/bmjopen-2014-005180

28. Sharma R, Vikas K Desai,1 and Abhay Kavishvar; Assessment of Immunization Status in the Slums of 
Surat by 15 Clusters Multi Indicators Cluster Survey Technique Indian J Community Med. 2009 34(2): 152-5. doi: 10.4103/0970-0218.51222

29. Kusuma YS, Kumari R, Pandav CS, Gupta SK, Migration and immunization: Determinants of childhood immunization uptake among socioeconomi- cally disadvantaged migrants in Delhi, India. Tropical Medicine and International Health 2010 Nov;15 (11):1326-32.

doi: 10.1111/j.1365- 3156.2010.02628.x

30. Banerjee J. Child Health and Immunization Status in an Unregistered Mumbai Slum. Thesis. Department of Global Health and Population, Harvard School of Public Health. USA. 2010 